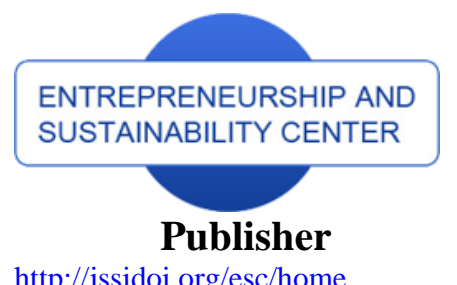

http://jssidoi.org/esc/home enterprise

europe

network

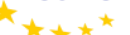

Business Support on Your Doorstep

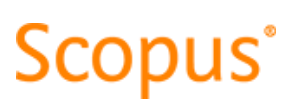

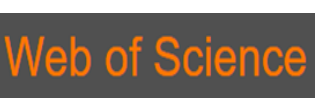

1) Clarivate

Analytics

\title{
COMPETITIVENESS AND SUSTAINABLE GROWTH ANALYSIS OF THE EU COUNTRIES WITH THE USE OF GLOBAL INDEXES' METHODOLOGY*
}

\author{
Dana Kisel'áková ${ }^{1}$, Beáta Šofranková 2 , Veronika Čabinová ${ }^{3}$, Erika Onuferová $^{4}$ \\ 1,2,3,4 University of Prešov in Prešov, Faculty of Management, \\ Konštantínova 16, 08001 Prešov, Slovak Republic \\ E-mails: ${ }^{1}$ dana.kiselakova@unipo.sk; ${ }^{2}$ beata.sofrankova@unipo.sk; ${ }^{3}$ veronika.cabinova@smail.unipo.sk; \\ eika.onuferova@smail.unipo.sk
}

Received 25 August 2017; accepted 10 January 2018; published 30 March 2018

\begin{abstract}
The issue of countries' competitiveness and sustainable economic growth is constantly at the centre of interest and represents the frequent object of research in economic theory as well as economic practice. The multi-criterial approach and the assessment methodologies relating to the global competitiveness have been dynamically adjusted over the recent years to reflect the current globalization trends in the world economy. The main objective of this study is to analyse the objectivity and resulting values' deviations of the Global competitiveness Index (GCI) and World Competitiveness Index (WCI) composite indexes that are currently considered to be the world's most respected and to identify the impact of key factors that affect the countries' competitive positions with a focus on Slovakia. The research study is realized within the group of EU (24) countries for the period $2006-2016$. The partial objective is to summarize the main starting points of the World Economic Forum (WEF) and Institute for Management Development (IMD) composing these indices, to identify their common features and different approaches that create differences in the results achieved. Then we analyzed the differences between the resulting rankings and the resulting scores of the GCI and WCI rated countries. In the next part, we focused on analyzing the position of Slovakia using the correlation and multiple regression analysis and identifying the interrelationships between individual pillars and the GCI score in order to determine the impact of key factors that influence the competitive position and sustainable growth of Slovakia and improve or worsen its position. Our results highlighted the economic and statistical context of GCI Slovakia development and the impact of the following key pillars and key factors: pillar P1 (P1: Institutions - Public trust in politicians), pillar P3 (P3: Macroeconomic environment - Government debt) and pillar P11 (P11: Business sophistication - Nature of competitive advantage). All three pillars, identified as crucial to the development of the overall Slovakias' GCI scores, occupy unflattering positions in the comparison of pillar rankings. Therefore, we conclude that it is necessary to clarify the causes of their development and eliminate these identified factors as soon as possible. The results can be seen as beneficial to countries' economic policies in increasing global competitiveness.
\end{abstract}

Keywords: competitiveness, global indexes, multi-criterial approach, key pillars, key factors, regression analysis, regression model

Reference to this paper should be made as follows: Kiseláková, D.; Šofranková, B.; Čabinová, V.; Onuferová, E. 2018. Competitiveness and sustainable growth analysis of the EU countries with the use of Global Indexes' methodology, Entrepreneurship and Sustainability Issues 5(3): 581-599. http://doi.org/10.9770/jesi.2018.5.3(13)

JEL Classifications: O11, O57, F 43, F62, F63

* This work was supported by the Slovak Research and Development Agency under the contract No. APVV-15-0322. 


\section{Introduction}

Currently, the issue of competitiveness is the object of many economic analyses, but there is no internationally unified interpretation and understanding of this concept. Competitiveness is still one of the key indicators of the performance assessment of economies and a "mirror" of the success of countries at the global level. The way of assessing the level of competitiveness is difficult as well as the definition and understanding of the concept itself (Staníčková, Melecký 2011). As reported by authors Ivanová, Kordoš, Habánik (2015), the international competitiveness represents one of the alternative performance economic indicators which allows monitoring of all important factors that affect not only economic performance but also many social aspects and social maturity of the country. However, despite all the definitions, in professional literature there is no clearly defined attitude to the issue of competitiveness as well as its measurement and the way of expression. As reported by Loo (2012), the most respected organizations dealing with the assessment of nation's competitiveness at the global level are the World Economic Forum (WEF) and the Institute for Management Development (IMD). Both institutions are Switzerland - based institutions and use macro and microeconomic concepts to study the efficiency of the public and private sector as well as the overall infrastructure that forms and affects national competitiveness. For this reason, we decided to focus on the analysis of the competitiveness indexes methodology - the Global Competitiveness Index (GCI) and the World Competitiveness Index (WCI) that are create by mentioned institutions; another purpose was to identify the key factors improving the countries' competitive position on the international market.

The World Economic Forum (WEF) defines competitiveness as "the set of institutions, policies and factors that determine the level of productivity of the country". Productivity of the country means a country's ability to maintain a high level of income, but it is also one of the main factors influencing the return on investment that reflects the growth potential of the specific economy. In summary, competitiveness is understood as the ability of the country to achieve sustained high growth rates of GDP per capita (Sala-i-Martín et al. 2015). The Institute for Management Development (IMD) provides another definition of competitiveness in its yearbooks (IMD: World Competitiveness Yearbook 2014). It defines this term as an area of economic theories which analyses all the facts and policies forming the country's ability to create and continually construct an environment maintaining enterprise value creation, prosperity and well-being for its people. World competitiveness is understood as the country's ability to manage overall available resources and opportunities in order to increase the prosperity of its inhabitants.

\section{Literature Review of the Selected Empirical Studies}

Many empirical studies have been dealing with the analysis of the countries' global competitiveness based on the international and reputable indexes (Tomčík, Bondareva 2015; Chudárková 2012; Popescu, Sima, Nica, Gheorghe 2017; Majerová, Horúcková 2014; Nečadová 2015; Despotović, Cvetanović, Nedić, Despotović 2016 and others). Another group of authors is focused on the comparison of countries' competitiveness measured especifically by the GCI and WCI scores and their positions within the world rankings. Balcarová (2015) studied whether the differences in competitiveness among individual EU economies by using the GCI and WCI indicator are during the analysed period decreasing or not. The convergence was confirmed only in the case of using the GCI indicator. More detailed analysis of the methodical background and possible subjectivity of indexes GCI and WCI was provided also by Dudás (2013). Author focused mainly on the role of business sector in the creation of these indexes. The analysis of changes and the current position in competitive rankings of this informal group of Central European countries was also performed by Ružeková, Kaštáková, Žatko (2016). However, the results were compared with other multi-criteria index - Doing Business Index (DBI). Tokárová (2015) also analysed the theoretical views on the issues of national economies' competitiveness based on the indexes GCI, WCI and 


\section{The International Journal}

ENTREPRENEURSHIP AND SUSTAINABILITY ISSUES

ISSN 2345-0282 (online) http://jssidoi.org/jesi/

2018 Volume 5 Number 3 (March)

http://doi.org/10.9770/jesi.2018.5.3(13)

another one - SCI (Sustainability - Adjusted Global Competitiveness Index). Based on the data provided by the WEF and IMD, author Loo (2015) focused on the competitiveness analysis of the BRIC nations over the 15 years. He identified the key challenges faced by each nation and highlighted the implications for the future development and proposed three factors that may have influenced the results: democracy, colonialism and religion. In another study, Loo (2012) investigated the competitiveness of the top five nations during the decade from 2000 to 2009. On the basis of the GCI and WCI positions' development and trends, he subsequently forecasted the top five nations in the next decade from 2010 - 2019. The contribution was also devoted to the comparison of the calculation methodology within the both indexes. The analysis of selected factors within certain pillars was done in the study by authors Mikušová Meričková, Nemec, Murray Svidroňová, Pischko (2017). To keep up with global and national competition require to follow up the level of gross domestic product as one of the main indicator measuring economic sustainability. This conclusion reached Jurigová, Tučková, Solenes (2017) in their study. Different view is provided in study by Gavurova, Virglerova, Janke (2017). They trying to find the answer how fast can changes in trust on economic growth and other determinants are visible in changes in economic growth and competitiveness of countries. Dobrovič, Korauš, Dančišinová (2016) analyzed sustainable economic development of Slovakia differently, through factors determining optimal tax collection.

\section{Objectives, Methodology and Methods}

Early concepts of measuring the competitiveness at the international level began to emerge since the 1980s. According to authors Ochotnický, Lajzová, Kiseláková (2011), the assessment methodologies relating to global competitiveness have been adjusted to correspond with the current globalization trends in the world economy. As reported by Abrhám, Herget (2013), approaches of institutions assessing competitiveness differ from each other according to the number and type of selected indicators, weights allocated to them or other particular approaches for their evaluation. Some institutions are focused on institutional quality and the role of government in the country, while others put emphasis on the technological aspects of competitive advantage. Another group of institutions prefer multi-criteria evaluation based on many different indicators grouped into various areas. Gordiaková (2011) adds that despite differences in the methodologies used to assess competitiveness by using different approaches (e.g. by using indexes with applications for statistical resources), most of methods are connected by high multi-criteriality and complexity. The main aim of research study is to analyse the objectivity and resulting values' deviations of the GCI and WCI composite indexes within the group of EU(24) countries during the years 2006 - 2016 and to identify the impact of key factors that affect the countries' competitive positions with a focus on Slovakia.

The first partial aim is to summarize the main WEFs' and IMDs' approaches used to compile the GCI and WCI indexes while pointing out to their common features and different approaches that cause different results and also affect their information value. The second partial aim is to analyse the development of positions in rankings as well as the modified GCI and WCI score within the EU(24) countries. We were focused on revealing the deviations of resulting values in the case of both indexes, which were caused by application of different methodology. Subsequently, we analysed the differences between the countries' final positions in rankings and the final GCI and WCI scores of selected countries. The third partial aim was to analyse the Slovakia's position within the rankings by means of the correlation and multiple regression analysis and also reveal the interconnections among individual pillars and the overall GCI score to identify the impact of key factors that improve or worsen its position and also affect the competitive position and sustainable growth of the Slovak Republic.

Based on defined objectives, the following research questions are set out in the study:

RQ1: What are the main differences in approaches and methodology of creating the GCI and WCI indexes that cause the deviations in the resulting score of national economies? 


\section{The International Journal}

ENTREPRENEURSHIP AND SUSTAINABILITY ISSUES

ISSN 2345-0282 (online) http://jssidoi.org/jesi/

2018 Volume 5 Number 3 (March)

http://doi.org/10.9770/jesi.2018.5.3(13)

RQ2: Did the EU(24) countries achieve the same positions within the world competitiveness rankings created by WEF as well as by IMD in years $2006-2016$ ?

RQ3: Which factors can be considered as the key factors influencing a better position and criteria for sustainable economic growth in the analysed countries with a focus on Slovakia?

In order to meet the data completeness condition and to increase the effectiveness of the results comparison, we had to make two adjustments:

- Based on the WEFs' and IMDs' world rankings we created a modified ranking of the European Union countries during the same period 2006 - 2016. We were forced to exclude 4 countries (Cyprus, Malta, Lithuania and Latvia) as they were not included in the IMDs' world rankings or did not provide all the data necessary for the correct comparison of the same number of selected countries.

- The GCI score ranges from 0 to 7, but the WCI score is in the range from 0 to 100 . This difference complicated the countries' comparisons so the resulting WCI scores were transformed by a simple adjustment of the original upper range to a score moving in the same range as the GCI index:

-

where $\quad \mathrm{WCI}_{\mathrm{a}}-\mathrm{WCI}$ adjusted,

$\mathrm{WCI}_{\mathrm{a}}=\left(\mathrm{WCI}_{\mathrm{b}} / 7\right) * 100$

$\mathrm{WCI}_{\mathrm{b}}-\mathrm{WCI}$ basic.

For the purposes of meeting the objectives of this study, we performed a correlation and multiple regression analysis among selected variables in the analytical part 4 with a focus on Slovakia. Within the correlation analysis, we were concentrated on examining the interdependencies among the individual pillars of the GCI(SR - Slovak Republic). The regression analysis is a summary of statistical methods and procedures that are used to study the interaction among two or more variables (usually numeric), by means of a regression model. The aim of the regression analysis is:

- finding the regression equation that describes the relationship between the studied variables,

- coefficient estimates as a confirmation of the theory of the relationship between the variables,

- prediction of the dependent variable values and finding an impact of key variables as key factors.

For analyzing the relationship among variables, a linear regression model was used (Schneider, Spieth 2013). This model was adapted to investigate the relationship among one dependent variable and independent variables. The regression model is a mathematical relationship that simply characterizes relation among variables. In our study we expressed the dependence of the Y variable (GCI) values on the selected independent X variables (Pillars 1-12 in GCI) analyzed in the section 4.5.

\subsection{Global Competitiveness Index (GCI) and Calculation Methodology}

Since 2005, the internationally reputable organization World Economic Forum has based its analysis of the competitiveness on the Global Competitiveness Index (GCI), a comprehensive tool integrating microeconomic and macroeconomic aspects of national competitiveness into one overall index. The GCI index captures the fact that government and business leaders have known for a long time: competitiveness is a complex phenomenon and the overall level of competitiveness of the country can be improved only through a wide range of reforms in different areas. The GCI index also highlights the fact that countries have different priorities depending on their level of development. The primary goal of this institution is to provide certain overview to all interested parties and stimulate discussion about best strategies and policies that can help countries to overcome barriers of increasing their competitiveness (Sala-i-Martín et al. 2014). As reported by Gordiaková (2011), the Global Competitiveness Index is composed of 12 general economic pillars which play an important role in its quantification. Individual pillars are integrated into three groups on the basis of their content and orientation and they are called "sub-indexes" according to the theory of M. Porter - basic requirements, efficiency enhancers and 
innovation and sophistication factors. Thus, we can divide the national economies into three stages of development and two "in transition" stages based on the per capita GDP per capita and the share of mineral goods in total exports. We can explore the ability of increasing the national economy through a set of factors, policies and institutions that indicate the level of productivity of the country.

The weights of the individual subindexes are different depending on the stage of development of economies, whereas the weights of individual indicators remain constant. For countries considered to be "in transition", the weights change smoothly as a country develops, reflecting the smooth transition from one stage of development to another. The GCI indicator "penalizes" those countries that are not ready for progress to the next stage of development (Ivanová, Kordoš 2015). Computation of the GCI indicator is based on successive aggregations of scores from the individual indicator level (the most disaggregated level) all the way up to the overall score of the GCI indicator.

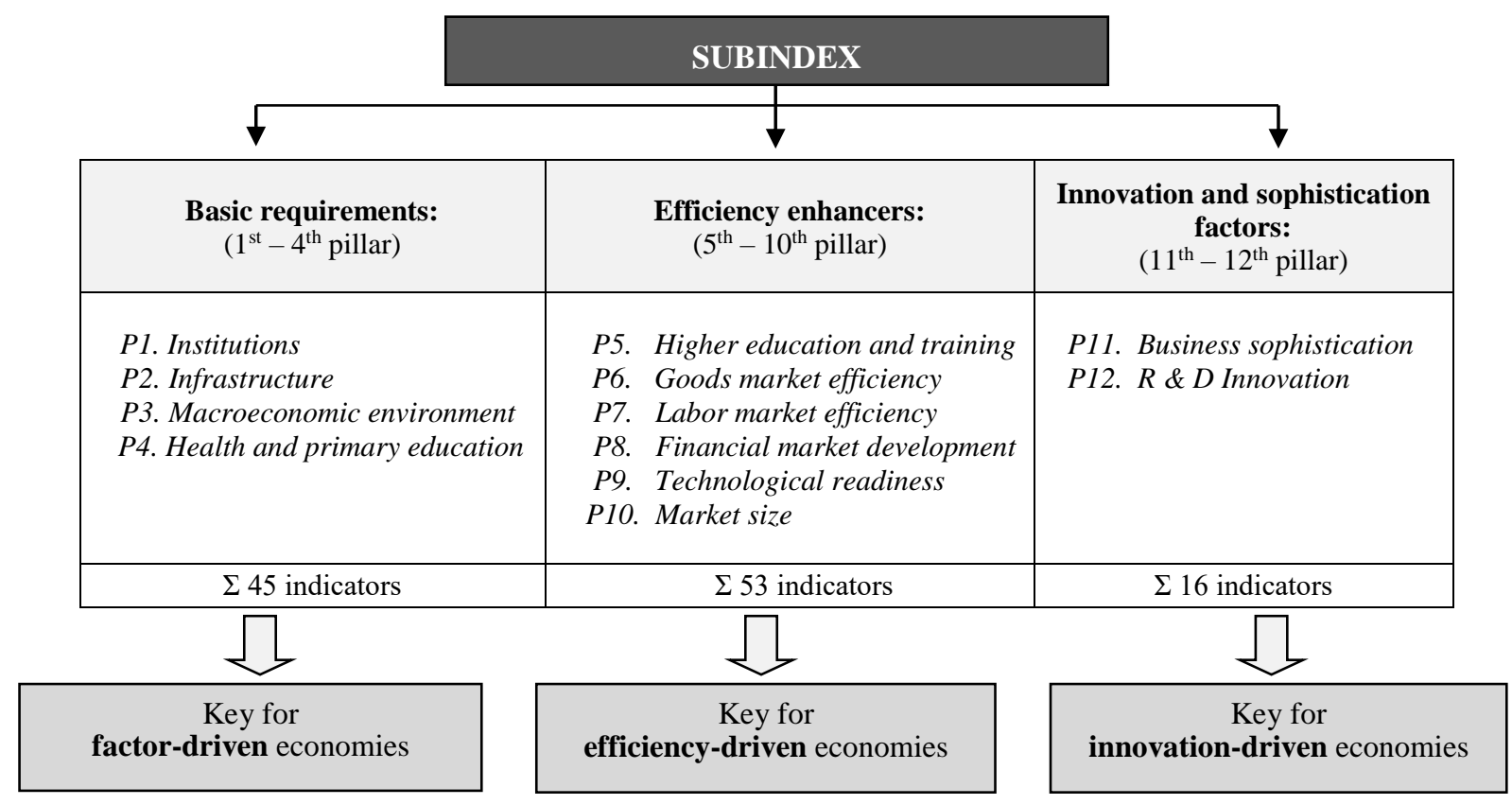

Fig.1. The Global Competitiveness Index Framework

Source: Sala-i-Martín et al. (2016)

As reported by Paraušić, et al. (2014), the WEF evaluates international competitiveness by the GCI indicator which is based on large number of variables grouped into 12 basic pillars of competitiveness. To assess these variables are used so-called "soft and hard data". "Hard data" are gathered from publicly available sources (International Monetary Fund, World Bank, UNESCO, World Health Organization, etc.). "Soft data" are received by the Executive Opinion Survey (EOS) performed in each partner country. Respondents express their degree of agreement or disagreement with the survey statements on a scale from 1 to 7 , where 1 represents the worst possible situation and 7 the best possible situation. The definition of the individual factors according to the pillars (P1-P12) is closer defined in the article "Analytical View on the Competitiveness Development in the Slovak Republic and in the EU" (Kiseláková, Šofranková, Čabinová 2016).

\subsection{World Competitiveness Index (WCI) and Calculation Methodology}


The World Competitiveness Yearbook has been published by the Institute for Management Development (IMD) since 1989 and it is regarded to be the most comprehensive report concerning the competitiveness of countries. Based on the World Competitiveness Index (WCI) countries are analysed and ranked according to their ability to use competencies and opportunities to achieve a higher prosperity. The overall economic environment of countries can be divided into four key factors and each of these factors is made up of five other subfactors (IMD 2014). Gordiaková (2011) adds that the ach sub-factor has the same weight (5\%) that is fixed and independent on the number of criteria it contains.

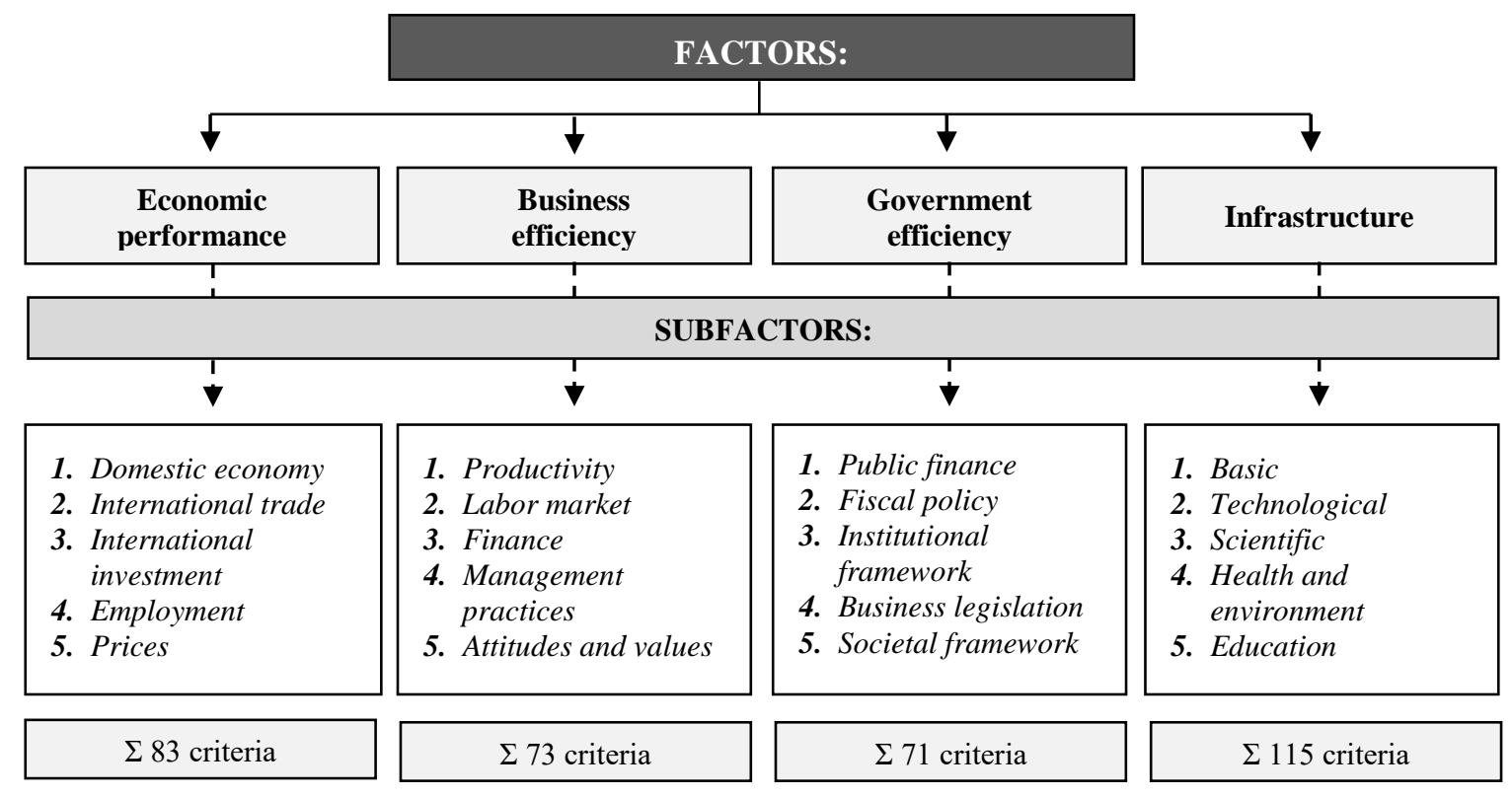

Fig.2. The World Competitiveness Index Framework Source: Bris (2016)

As reported by Dudáš (2012), the first factor "Economic performance" is aimed at evaluating the domestic macroeconomic environment, international trade and investment, the actual state and development of employment and prices. Within the group of subfactors "Business Efficiency" the attention is paid to the evaluation of labor market and its productivity, the situation and future trends in the financial market but also practices of managers, their know-how, values or attitudes. The factor "Government Efficiency" examines the state of public finances, fiscal policy of the state, legislation relating to the business environment and societal framework of the economy. The last factor "Infrastructure" assesses the availability and the level of different types of infrastructure (basic, technological, scientific, medical or educational).

The IMD relies on secondary (hard) data and primary (soft) data to quantify the competitiveness of countries. Secondary data, so called "hard" statistical data are easily quantified and they are compiled from international, national and regional organizations, for example the OECD, World Bank, United Nations and many other partner institutes around the world. "Soft" data are complement to the "hard" data in order to help measure competitiveness issues that are not easily quantified, for example perception of corruption, quality of life, management practices, labor relations, environmental concerns and many others. They are compiled from annual Executive Opinion Survey (EOS) which provides actual and more detailed information reflecting economic reality in the country. The survey is sent to participants - top managers and answers are detected as a measure of 
agreement or disagreement with the prepared questions or statements. The survey is conducted from January to April and responses are returned directly to IMD headquarters (IMD 2016).

\section{Results and Discussion}

\subsection{Comparison of Basic Approaches to Global Competitiveness by the WEF and IMD}

To answer the RQ1 we have focused on summarizing and evaluating the common features, advantages, disadvantages and differences in the methodology applied to the construction of the GCI as well as WCI index. These findings have been gathered primarily from the Global Competitiveness Report (GCR) and the World Competitiveness Yearbook (WCY). The intention was to provide a brief overview of the different approaches and overall activity of these institutions that were reflected in the deviations of score achieved and countries' positions within the competitiveness rankings.

At first, we have focused on assessing common features of the WEFs' and IMDs' approaches to global competitiveness:

- both institutions publish rankings and comprehensive global competitiveness reports and compare significant world economies every year,

- both institutions are accepted at a high level by the governments of involved countries, therefore they are considered the most authoritative in the world,

- both institutions use various and very similar data in the processing of results - statistical data (gross, quantitative) as well as the data obtained as a result of the questionnaire survey (soft, qualitative),

- country assessment methodology for both institutions is based on the same theoretical concept (multi-criteria approach),

- the methodology, number of indicators and participating countries within the WEFs' and IMDs' reports are changing almost every year which complicates result comparability over time,

- the interpretation of the results is the same for both institutions - higher score of the GCI or WCI indicator means higher competitiveness.

Subsequently, we have analyzed the WEFs' approaches to global competitiveness and summarized them into the following points:

a) the WEF equates competitiveness with productivity that sets a sustainable level of prosperity that a country may achieve,

b) the WEF focuses on the government's role in providing a rising living standard to their citizens,

c) the GCI indicator tries to reflect why some countries have been better at providing high and rising living standard to their citizens than others,

d) the WEF released its first Global Competitiveness Report in 1979,

e) the WEFs' full reports are publicly available without any fees,

f) the WEF is currently conducting a Global Competitiveness Survey in 138 countries and cooperating with 160 partner institutions,

g) the competitiveness of countries is evaluated through the GCI indicator which is based on 12 pillars grouped into 3 subindexes whereas the weights of individual subindexes depends on the country's development,

h) overall, the GCI indicator includes 114 individual indicators, primary data ("soft data") represents about 2/3 of the total data, the remaining 1/3 consist of secondary data ("hard data") (Blanke 2011; Loo 2015; Sala-i-Martín et al. 2015; Sala-i-Martín et al. 2016). 
By analogy, we examined the IMDs' approaches to global competitiveness in identical areas:

a) the IMD equates competitiveness with a combination of competencies in economic growth and mindset in value-added areas,

b) the IMD suggests collaboration between governments and enterprises to manage resources to achieve sustainable progress,

c) the WCI indicator focuses on how nations and enterprises manage the totality of their competitiveness to achieve long-term prosperity,

d) the IMD released its first World Competitiveness Yearbook in 1989,

e) the IMDs' full yearbooks are available for a fee,

f) the IMD is currently conducting a World Competitiveness Survey in 61 countries and cooperating with 55 partner institutions,

g) the competitiveness of countries is evaluated through the WCI indicator which is based on 4 key factors divided into a total of 20 subfactors whereas the weights of individual subfactors are fixed $(5 \%)$,

h) overall, the WCI indicator includes 342 individual criteria,

i) primary data ("soft data") represents about $1 / 3$ of the total data, the remaining $2 / 3$ consist of secondary data ("hard data") (IMD 2016; Loo 2015).

\subsection{Analytical View of the EU(24) Countries' Competitive Position in the WEFs' and IMDs' Rankings}

The following part of the paper is focused on the analysis and comparison of the EU(24) countries' competitive position development over the years 2006 - 2016 in the context of the GCI and WCI indexes. The resulting WCI scores were transformed by a simple adjustment of the original upper range to a score moving in the same range as the GCI index. This adjustment was necessary in order to make the comparison of those indexes easier.

During the years 2006 - 2016, the average GCI score for the selected European countries was at the level of 4.79; WCI's average score achieved a slightly lower value (4.72). The development of the average GCI score within the EU(24) countries had a relatively stable trend, scores ranged from a minimum value of 4.73 recorded in 2009 and 2010 , up to the maximum value of 4.93 reached in 2006. Overall, the highest score of the GCI indicator was reached by Finland in 2006 (5.76), vice versa, the lowest values was indicated in 2009 and 2010 by countries such as Bulgaria, Romania or Greece. This fact was caused also by consequences of the financial and economic crisis. However, the positive fact has occurred since 2013 and the development of the GCI score of the EU(24) countries has recorded a growing trend.

The competitiveness development of the EU(24) countries over the years 2006 - 2016 quantified on the basis of the WCI indicator was fluctuating and unstable, especially from 2006 to 2012, when the average WCI values ranged from 4.41 to 4.96. In the following two years, the negative trend continued constantly. Even in 2014, the WCI average score stagnated almost at the same level as in year 2008. Fortunately, since this critical year the development of the average WCI score has improved significantly and it has increased by $15.53 \%$ to the level of 5.23. When comparing the average GCI score development, we can notice much more progressive positive trend, but at the expense of stable development of the average WCI scores within the EU(24) countries. Overall, the highest average WCI score was unlike the GCI score achieved in 2016 (5.23), the lowest value was recorded in 2006. It is interesting that the most successful year in the case of GCI's best score was year 2006. 


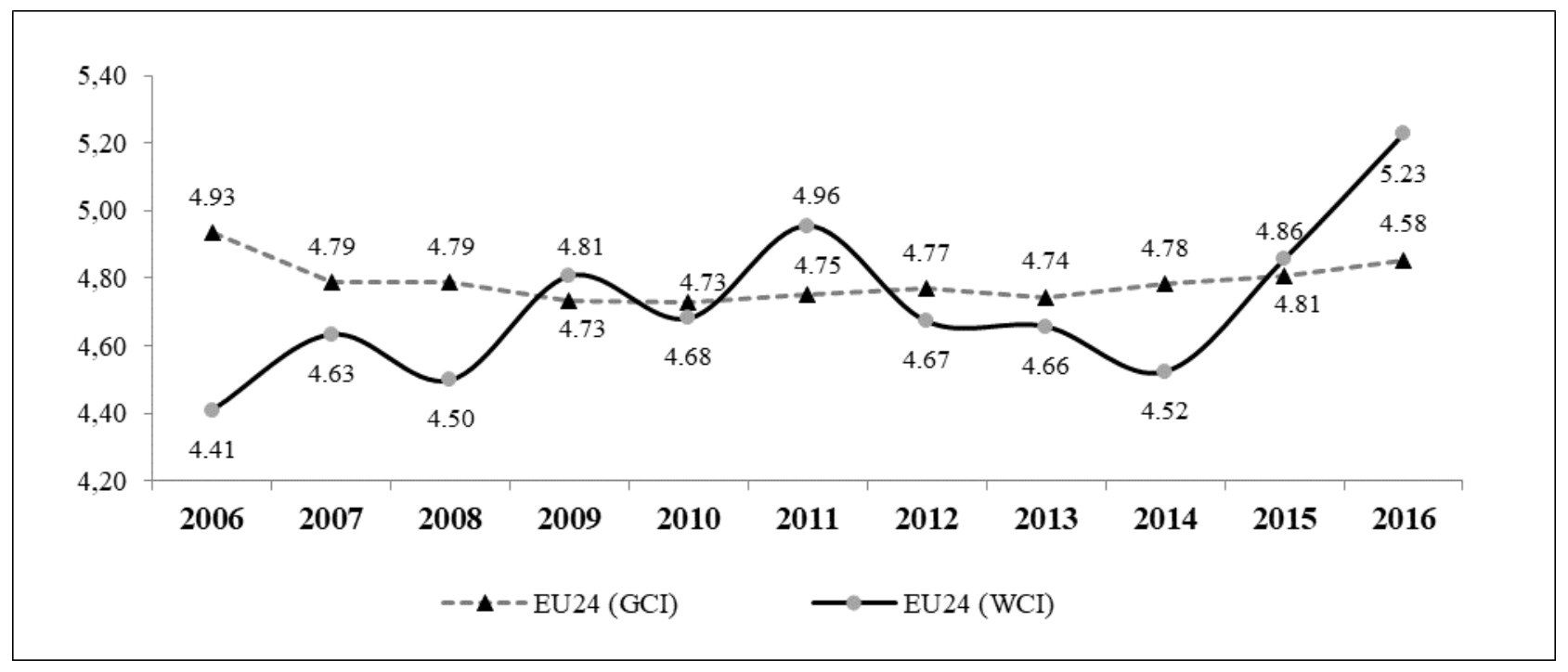

Fig.3. Development analysis of the GCI and $\mathrm{WCI}_{\mathrm{a}}$ scores within the $\mathrm{EU}(24)$ countries over the years $2006-2016$

Source: own processing based on the WEFs' and IMDs' annual reports and datasets

In conclusion of performed competitiveness analysis of the $\mathrm{EU}(24)$ countries it is necessary to note the following facts:

- During the analysed years 2006 - 2016, the average GCI score of the EU(24) countries has decreased by $1.62 \%$, vice versa, the positive increase of $18.52 \%$ was noticed in the case of the average WCI score. This fact undoubtedly gives rise to some confusion and questions about the actual competitiveness development within the group of EU(24) countries.

\subsection{Comparison of the EU(24) Countries' Competitiveness Development Based on the WEFs' and IMDs' Rankings}

After assessing the GCI and WCI development within the EU(24) countries during the monitored years 2006 2016 we have analysed the development of their positions within the WEF and IMD rankings.

Based on the average GCI score, the top performers within the EU were Sweden (5.53), Finland (5.50) and Germany (5.48). It is interesting that the overall GCI score of these countries have decreased, but countries were able to maintain the high rankings and do not let the GCI score fall below the level of 5.30. The biggest decrease of $6.25 \%$ in the GCI score to the value of 5.40 was recorded in the case of Finland. In the recent years, the Sweden's leadership within the EU(24) countries has been threatened. Germany is becoming the biggest favourite, its score in 2016 (5.60) was the highest among all EU(24) countries and during the analysed years 2006 - 2016 the score did not drop by $1 \%$. The weakest members of the analysed group are countries such as Greece (4.03), Croatia (4.12) and Romania (4.14), whose average GCI score was deep below the EU(24) countries. Based on the average GCI values, the Slovak Republic ranked $20^{\text {th }}$ during the years 2006 - 2016; however, its average position has been continually improving since 2013 . The strongest negative drop by 4 positions in the WEF rankings in 2016 compared to 2006 was recorded for countries such as Denmark, Finland, Greece, Hungary, Slovakia and Slovenia. On the other side, the most significant positive shift by 5 positions and more was recorded in the case of Bulgaria and Poland. 
Table 1. Comparison of the EU(24) countries' positions within the WEFs' and IMDs' rankings

\begin{tabular}{|c|c|c|c|c|c|c|c|c|}
\hline & \multicolumn{2}{|c|}{2006} & \multicolumn{2}{|c|}{2016} & \multicolumn{2}{|c|}{$\begin{array}{l}\text { Position changes } \\
(2006-2016)\end{array}$} & \multicolumn{2}{|c|}{$\begin{array}{c}\text { A verage position } \\
(\varnothing 2006-2016)\end{array}$} \\
\hline & WEF & IMD & WEF & IMD & WEF & IMD & WEF & IMD \\
\hline Austria & 7 & 5 & 10 & 10 & -3 & -5 & 7 & 8 \\
\hline Belgium & 9 & 11 & 7 & 9 & 3 & 2 & 8 & 10 \\
\hline Bulgaria & 24 & 20 & 19 & 22 & 6 & -2 & 21 & 21 \\
\hline Croatia & 22 & 24 & 23 & 24 & -1 & 0 & 23 & 24 \\
\hline Czech Republic & 14 & 12 & 14 & 11 & 1 & 1 & 14 & 13 \\
\hline Denmark & 3 & 1 & 7 & 2 & -4 & -1 & 5 & 1 \\
\hline Estonia & 12 & 8 & 12 & 12 & 0 & -4 & 12 & 12 \\
\hline Finland & 1 & 3 & 5 & 8 & -4 & -5 & 2 & 6 \\
\hline France & 8 & 13 & 10 & 13 & -2 & 0 & 9 & 11 \\
\hline Germany & 4 & 10 & 2 & 6 & 3 & 4 & 3 & 5 \\
\hline Greece & 20 & 17 & 24 & 23 & -4 & -6 & 24 & 23 \\
\hline Hungary & 18 & 16 & 22 & 20 & -4 & -4 & 19 & 18 \\
\hline Ireland & 10 & 4 & 10 & 3 & 1 & 1 & 11 & 7 \\
\hline Italy & 19 & 21 & 17 & 16 & 3 & 5 & 17 & 19 \\
\hline Luxembourg & 11 & 2 & 10 & 5 & 2 & -3 & 10 & 2 \\
\hline Netherlands & 5 & 7 & 2 & 4 & 4 & 3 & 4 & 4 \\
\hline Poland & 21 & 23 & 15 & 14 & 6 & 9 & 16 & 16 \\
\hline Portugal & 16 & 18 & 17 & 17 & -1 & 1 & 15 & 15 \\
\hline Romania & 23 & 22 & 21 & 21 & 3 & 1 & 22 & 22 \\
\hline Slovak Republic & 17 & 15 & 21 & 18 & -4 & -3 & 20 & 17 \\
\hline Slovenia & 15 & 19 & 19 & 19 & -4 & 0 & 18 & 20 \\
\hline Spain & 13 & 14 & 14 & 15 & -1 & -1 & 13 & 14 \\
\hline Sweden & 2 & 6 & 4 & 1 & -2 & 5 & 1 & 3 \\
\hline United Kingdom & 6 & 9 & 4 & 7 & 3 & 2 & 6 & 9 \\
\hline
\end{tabular}

Source: own processing based on the WEFs' and IMDs' annual reports and datasets

Based on the average WCI score reached by the EU(24) countries during the years 2006 - 2016, the competitive leaders were definitely Denmark (6.09), Luxembourg (6.04) and Sweden (5.95) whose resulting scores increased on average by $12.35 \%$ compared to 2006 . In 2016, originally leading Finland ranked up to $6^{\text {th }}$ position on average with the WCI score at the level of 5.63, but its position has been threatened by Ireland in recent years. Over the analysed period, Germany (5.80) reached $5^{\text {th }}$ position on average within the EU(24) evaluated countries. The lowest WCI scores were reached by Croatia (3.09) and country was significantly behind the other national economies. The penultimate position belonged to Greece (3.54) and $3^{\text {rd }}$ position as the worst competitive economy over the years 2006 - 2016 was reached by Romania (3.56). Since 2012, Romania has acquired a positive trend of development and threatens countries like Bulgaria or Slovakia. The most significant drop in EU(24) IMD rankings was recorded in the case of Greece that dropped from its initial $17^{\text {th }}$ place in 2006 to the penultimate position in 2016. A similar negative decline also occurred in Finland and Austria which dropped by 5 positions compared to the 2006. On the other hand, the most significant positive shift (9 positions up) was recorded in the case of Poland.

After assessing the EU(24) countries' position development within the WEFs' and IMDs' rankings, we finally focused on summarizing their resulting average positions over the years 2006 - 2016 in order to reveal the most significant deviations in countries' positions and also answer a RQ2: 
- The identical average position in the WEFs' and IMDs' rankings was reached in the case of Bulgaria, Estonia, Netherlands, Poland, Portugal and Romania.

- The worse average position in the WEFs' rankings compared to the IMDs' rankings were reached by Luxembourg (8 positions), Ireland (4 positions), Denmark (4 positions), Slovakia (3 positions), Hungary (1 position), the Czech Republic (1 position) and Greece (1 position).

- The worse average position in the IMDs' rankings compared to the WEFs' rankings were achieved in the case of Finland (4 positions), England (3 positions), Italy (2 positions), Belgium (2 positions), France (2 positions), Germany (2 positions), Sweden (2 positions), Austria (1 position), Croatia (1 position) and Spain (1 position).

\subsection{Quantification of Interdependencies Among Pillars of the GCI(SR) by Applying Correlation Analysis}

In the next part, we aimed at the deeper cause analysis of the global competitiveness development in the case of Slovakia and examined the interdependencies among the individual pillars of the GCI(SR). The correlation analysis was performed only for the GCI index for the period 2006 - 2016 because of the limitated WCI's input information. The overview of the GCI(SR) pillars' development and its average values for the selected years representing the input variables of the correlation analysis are presented in Table 2. Statistically quantified correlation among individuall pillars are shown in Table 3.

Table 2. Development of the GCI(SR) pillars and GCI(SR) average scores over the years 2006 - 2016

\begin{tabular}{|c|c|c|c|c|c|c|c|c|c|c|c|c|c|}
\hline & $1^{\text {st }}$ & $2^{\text {nd }}$ & $3^{\text {rd }}$ & $4^{\text {th }}$ & $5^{\text {th }}$ & $6^{\text {th }}$ & $7^{\text {th }}$ & $8^{\text {th }}$ & $9^{\text {th }}$ & $10^{\text {th }}$ & $11^{\text {th }}$ & $12^{\text {th }}$ & GCI(SR) \\
\hline 2006 & 3.98 & 3.72 & 5.41 & 5.95 & 4.45 & 4.59 & 4.73 & 4.95 & 4.12 & 4.16 & 4.21 & 3.43 & 4.55 \\
\hline 2007 & 3.99 & 3.78 & 4.92 & 5.88 & 4.42 & 4.66 & 4.76 & 5.02 & 4.08 & 3.81 & 4.26 & 3.42 & 4.45 \\
\hline 2008 & 3.85 & 3.64 & 5.31 & 5.82 & 4.43 & 4.71 & 4.67 & 5.04 & 4.35 & 3.94 & 4.33 & 3.28 & 4.40 \\
\hline 2009 & 3.74 & 3.89 & 5.14 & 5.68 & 4.37 & 4.67 & 4.78 & 4.82 & 4.61 & 4.05 & 4.29 & 3.12 & 4.31 \\
\hline 2010 & 3.60 & 4.19 & 5.20 & 6.07 & 4.49 & 4.34 & 4.66 & 4.61 & 4.48 & 3.97 & 4.12 & 2.95 & 4.25 \\
\hline 2011 & 3.46 & 4.23 & 4.92 & 6.04 & 4.50 & 4.36 & 4.47 & 4.44 & 4.54 & 3.99 & 4.00 & 2.91 & 4.19 \\
\hline 2012 & 3.44 & 4.23 & 4.87 & 6.03 & 4.50 & 4.37 & 4.20 & 4.45 & 4.46 & 4.00 & 4.02 & 2.98 & 4.14 \\
\hline 2013 & 3.32 & 4.12 & 4.91 & 6.07 & 4.44 & 4.25 & 4.24 & 4.49 & 4.16 & 4.03 & 3.95 & 3.02 & 4.10 \\
\hline 2014 & 3.33 & 4.21 & 5.23 & 5.55 & 4.65 & 4.36 & 3.95 & 4.50 & 4.37 & 4.03 & 4.00 & 3.18 & 4.15 \\
\hline 2015 & 3.40 & 4.30 & 5.20 & 6.00 & 4.60 & 4.40 & 3.90 & 4.40 & 4.60 & 4.00 & 4.10 & 3.30 & 4.22 \\
\hline 2016 & 3.50 & 4.20 & 5.30 & 6.00 & 4.50 & 4.50 & 4.00 & 4.60 & 4.80 & 4.00 & 4.10 & 3.30 & 4.30 \\
\hline
\end{tabular}

Source: own processing based on the WEFs' and IMDs' annual reports and datasets

Table 3. Correlation analysis of the GCI(SR) pillars

\begin{tabular}{lccccccccccccc}
\hline \multicolumn{6}{l}{ Correlations among GCI and scores of GCI Pillars. Marked correlations are significant at $\mathbf{p}<\mathbf{0 . 0 5}\left(\mathbf{p}^{*}<\mathbf{0 . 0 1}\right)$} \\
\hline Kendall Tau & $\mathbf{1}^{\text {st }}$ & $\mathbf{2}^{\text {nd }}$ & $\mathbf{3}^{\text {rd }}$ & $\mathbf{4}^{\text {th }}$ & $\mathbf{5}^{\text {th }}$ & $\mathbf{6}^{\text {th }}$ & $\mathbf{7}^{\text {th }}$ & $\mathbf{8}^{\text {th }}$ & $\mathbf{9}^{\text {th }}$ & $\mathbf{1 0}^{\text {th }}$ & $\mathbf{1 1}^{\text {th }}$ & $\mathbf{1 2}^{\text {th }}$ \\
\hline GCI(SR) & $\mathbf{0 . 8 1 8 2}$ & $\mathbf{- 0 . 5 1 3 8}$ & $\mathbf{0 . 4 6 3 0}$ & -0.3149 & -0.3740 & $\mathbf{0 . 5 8 7 2}$ & 0.4545 & $\mathbf{0 . 5 6 3 6}$ & -0.0545 & -0.1699 & $\mathbf{0 . 6 8 5 3}$ & $\mathbf{0 . 5 1 3 8}$ \\
p (value) & $\mathbf{0 . 0 0 0 4}^{*}$ & $\mathbf{0 . 0 2 7 8}$ & $\mathbf{0 . 0 4 7 4}$ & 0.1776 & 0.1093 & $\mathbf{0 . 0 1 1 9}$ & 0.0516 & $\mathbf{0 . 0 1 5 8}$ & 0.8153 & 0.4669 & $\mathbf{0 . 0 0 3 3} *$ & $\mathbf{0 . 0 2 7 8}$ \\
\hline
\end{tabular}

Source: own processing in programme STATISTICA 
The analyzed correlation among the overall GCI score and its individual pillars was confirmed in the case of 7 pillars: P1; P2; P3; P6; P8; P11; P12. The most significant dependence (0.8182) was found for the pillar P1: Institutions whose score reached the average value of 3.60 during the years 2006 - 2016 (see Table 4). Compared to other pillars we can consider this pillar as the second worst pillar. Based on the results, pillar P1: Institutions is key to the development of the GCI (SR) and it is essential to eliminate the causes to improve global competitiveness. Fabuš (2015) also points out that conditions for business of a state have an influence on its attractiveness for potential foreign investments.

\subsection{Regression Analysis of the GCI(SR) Development Trend Within Individual Subindexes}

On the basis of the regression analysis, we then analyzed the causal relations to maximize the output variable. In this case, it represents the output variable GCI(SR) (y). The purpose was to quantify the impact of individual pillars on the total index score, to identify the key factors that determine the country economic growth and to find out what change of pillars leads to the improvement/decline of the Slovakia's competitive position (to investigate the answer for RQ3).

Table 4. Average values of the GCI(SR) pillars over the years 2006 - 2016

\begin{tabular}{|lc|}
\hline Slovak Republic & $\varnothing 2006-2016$ \\
\hline P12: R\&D Innovation & 3.17 \\
P1: Institutions & 3.60 \\
P10: Market size & 4.00 \\
P2: Infrastructure & 4.05 \\
P11: Business sophistication & 4.13 \\
P7: Labor market efficiency & 4.40 \\
P9: Technological readiness & 4.42 \\
P6: Goods market efficiency & 4.47 \\
P5: Higher education and training & 4.49 \\
P8: Financial market development & 4.67 \\
P3: Macroeconomic environment & 5.13 \\
P4: Health and primary education & 5.92 \\
\hline
\end{tabular}

Source: own processing based on the WEFs' and IMDs' annual reports and datasets

The first subindex "Basic requirements" consist of 4 pillars (P1: Institutions, P2: Infrastructure, P3: Macroeconomic environment and P4: Health and primary education). The results of the statistical output of the estimated variables for the GCI are shown in Table 5. 
Table 5. The statistical output of the estimated variables within subindex "Basic requirements"

SUMMARY OUTPUT

\begin{tabular}{lr}
\hline \multicolumn{2}{c}{ Regression Statistics } \\
\hline Multiple R & 0,9819 \\
R Square & $\mathbf{0 , 9 6 4 2}$ \\
Adjusted R Square & 0,9403 \\
Standard Error & 0,0343 \\
Observations & 11 \\
\hline
\end{tabular}

ANOVA

\begin{tabular}{|c|c|c|c|c|c|}
\hline & $d f$ & SS & $M S$ & $F$ & Significance $F$ \\
\hline Regression & 4 & 0,1896 & 0,0474 & 40,4072 & 0,0002 \\
\hline Residual & 6 & 0,0070 & 0,0012 & & \\
\hline Total & 10 & 0,1967 & & & \\
\hline
\end{tabular}

\begin{tabular}{|c|c|c|c|c|c|c|c|c|}
\hline & Coefficients & Standard Error & t Stat & P-value & Lower 95\% & Upper 95\% & Lower $95,0 \%$ & Upper $95,0 \%$ \\
\hline Intercept & 0,7378 & 0,8381 & 0,8804 & 0,4125 & $-1,3128$ & 2,7885 & $-1,3128$ & 2,7885 \\
\hline 1 st Pillar & 0,5286 & 0,1034 & 5,1120 & 0,0022 & 0,2756 & 0,7817 & 0,2756 & 0,7817 \\
\hline 2 nd Pillar & 0,0462 & 0,1109 & 0,4163 & 0,6917 & $-0,2253$ & 0,3177 & $-0,2253$ & 0,3177 \\
\hline 3 rd Pillar & 0,2079 & 0,0620 & 3,3547 & 0,0153 & 0,0563 & 0,3595 & 0,0563 & 0,3595 \\
\hline 4 th Pillar & 0,0648 & 0,0724 & 0,8956 & 0,4049 & $-0,1123$ & 0,2420 & $-0,1123$ & 0,2420 \\
\hline
\end{tabular}

Source: own processing

The resulting of regression analysis expresses and confirms the logical, directly proportional relation among the pillar P1: Institutions, pillar P3: Macroeconomic environment and the overall GCI(SR) score. It means that the rise in the value of any of these 2 pillars will cause an increase in the total value of indices. The statistically significant relationship was not confirmed for the other pillars. The determination factor $\left(\mathrm{R}^{2}\right)$ is 0.9642 , which means that our model explains up to $96.42 \%$ of variability. Significance F value is 0.0002 , therefore we can state that the model has predictive capability. As the variables presents, the degree of impact of changing individual pillars varies. The regression analysis indicates that increasing the value of the pillar $P l$ by one unit will cause an increase in the overall index value by 0.5286 points and increasing the value of the pillar $P 3$ by one unit will cause an increase of GCI value by 0.2079 points. In the previous analysis (see Table 4), we found out that pillar P1: Institutions reached the second lowest average score (3.60) compared to all other pillars and it reached the penultimate position within the pillar rankings. On the basis of these results we can conclude that pillar Pl: Institutions (especially Public trust in politicians) is a key determinant of Slovakia's global competitiveness.

The second and largest group of sub-indexes "Efficiency enhancers" is composed of 6 pillars (P5: Higher education and training, P6: Goods market efficiency, P7: Labor market efficiency, P8: Financial market development, P9: Technological readiness and P10: Market size). The results of the statistical output of the estimated variables for the GCI are presented in Table 6.

Table 6. The statistical output of the estimated variables within subindex "Efficiency enhancers" 


\begin{tabular}{lr}
\hline \multicolumn{2}{c}{ Regression Statistics } \\
\hline Multiple R & 0,9170 \\
R Square & $\mathbf{0 , 8 4 0 9}$ \\
Adjusted R Square & 0,6021 \\
Standard Error & 0,0885 \\
Observations & 11 \\
\hline
\end{tabular}

ANOVA

\begin{tabular}{|c|c|c|c|c|c|}
\hline & $d f$ & SS & $M S$ & $F$ & Significance $F$ \\
\hline Regression & 6 & 0,1654 & 0,0276 & 3,5225 & 0,1216 \\
\hline Residual & 4 & 0,0313 & 0,0078 & & \\
\hline Total & 10 & 0,1967 & & & \\
\hline
\end{tabular}

\begin{tabular}{|c|c|c|c|c|c|c|c|c|}
\hline & Coefficients & Standard Error & t Stat & $P$-value & Lower 95\% & Upper 95\% & Lower 95,0\% & Upper 95,0\% \\
\hline Intercept & $-2,1139$ & 3,8277 & $-0,5523$ & 0,6102 & $-12,7412$ & 8,5134 & $-12,7412$ & 8,5134 \\
\hline 5 th Pillar & 0,4219 & 0,5954 & 0,7087 & 0,5176 & $-1,2311$ & 2,0749 & $-1,2311$ & 2,0749 \\
\hline 6 th Pillar & 0,1251 & 0,6228 & 0,2009 & 0,8506 & $-1,6041$ & 1,8544 & $-1,6041$ & 1,8544 \\
\hline 7 th Pillar & 0,0513 & 0,1697 & 0,3026 & 0,7773 & $-0,4197$ & 0,5224 & $-0,4197$ & 0,5224 \\
\hline 8 th Pillar & 0,5036 & 0,5079 & 0,9915 & 0,3776 & $-0,9066$ & 1,9138 & $-0,9066$ & 1,9138 \\
\hline 9 th Pillar & 0,0361 & 0,2159 & 0,1674 & 0,8752 & $-0,5634$ & 0,6357 & $-0,5634$ & 0,6357 \\
\hline 10 th Pillar & 0,3012 & 0,3408 & 0,8840 & 0,4266 & $-0,6449$ & 1,2473 & $-0,6449$ & 1,2473 \\
\hline
\end{tabular}

Source: own processing

The regression results didn't confirms the logical and directly proportional relation between the pillars P5 to P10 and the overall GCI(SR) score, because significance F value is higher than statistically significant level and in other words, the model has no predictive capability. The determination factor $\left(\mathrm{R}^{2}\right)$ is 0.8409 , which means that model would explains up to $84.09 \%$ of variability.

The last and smallest - but also the most important subindex - "Innovation and sophistication factors" consists of 2 pillars (P11: Business sophistication and P12: R\&D Innovation). As reported by authors Illmeyer, Grosch, Kittler, Priess (2016) in the current competitive market, innovation has become a crucial element for organizations, willing to grow. The results of the statistical output of the estimated variables for the GCI are shown in Table 7. 
The International Journal

ENTREPRENEURSHIP AND SUSTAINABILITY ISSUES

ISSN 2345-0282 (online) http://jssidoi.org/jesi/

2018 Volume 5 Number 3 (March)

http://doi.org/10.9770/jesi.2018.5.3(13)

Table 7. The statistical output of the estimated variables within the subindex "Innovation and sophistication factors"

SUMMARY OUTPUT

\begin{tabular}{lr}
\hline \multicolumn{2}{c}{ Regression Statistics } \\
\hline Multiple R & 0,8900 \\
R Square & $\mathbf{0 , 7 9 2 1}$ \\
Adjusted R Square & 0,7402 \\
Standard Error & 0,0715 \\
Observations & 11 \\
\hline
\end{tabular}

ANOVA

\begin{tabular}{lrrrrr}
\hline & $d f$ & $S S$ & $M S$ & $F$ & Significance $\boldsymbol{F}$ \\
\hline Regression & 2,0000 & 0,1558 & 0,0779 & 15,2443 & $\mathbf{0 , 0 0 1 9}$ \\
Residual & 8,0000 & 0,0409 & 0,0051 & & \\
Total & 10,0000 & 0,1967 & & & \\
\hline
\end{tabular}

\begin{tabular}{|c|c|c|c|c|c|c|c|c|}
\hline & Coefficients & Standard Error & t Stat & $P$-value & Lower 95\% & Upper 95\% & Lower 95,0\% & Upper $95,0 \%$ \\
\hline Intercept & 0,7263 & 0,7194 & 1,0096 & 0,3422 & $-0,9326$ & 2,3851 & $-0,9326$ & 2,3851 \\
\hline 11 th Pillar & 0,6157 & 0,2140 & 2,8776 & 0,0206 & 0,1223 & 1,1091 & 0,1223 & 1,1091 \\
\hline 12 th Pillar & 0,3190 & 0,1480 & 2,1559 & 0,0632 & $-0,0222$ & 0,6602 & $-0,0222$ & 0,6602 \\
\hline
\end{tabular}

Source: own processing

Finally, the last regression analysis has statistically confirm a direct relation between the pillar P11: Business sophistication and the GCI(SR). The determination factor $\left(\mathrm{R}^{2}\right)$ is 0.7921 , which means that our model explains $79.21 \%$ of variability. In this case also the model has predictive capability, because significance $\mathrm{F}$ value is 0.0019. We can state that the significant determinant of the overall GCI(SR) development is pillar P11: Business sophistication. The statistically significant relationship was not confirmed for the other pillar. The regression results indicate that increasing the value of this pillar by one unit will cause an increase in the value of the overall index by 0.6157 points. Over the years $2006-2016$, a deeper analysis showed that this pillar was the $5^{\text {th }}$ weakest pillar on average with a value of 4.13 (see Table 4). Taking into account the regression findings, we can conclude that pillar P11: Business sophistication is the third key determinant of the Slovakia's global competitiveness so it is necessary to identify the causes and try to eliminate them as soon as possible.

Table 8. The statistical output of the estimated variables for GCI by regression model SUMMARY OUTPUT

\begin{tabular}{lr}
\hline \multicolumn{2}{c}{ Regression Statistics } \\
\hline Multiple R & 0,9836 \\
R Square & $\mathbf{0 , 9 6 7 4}$ \\
Adjusted R Square & 0,9534 \\
Standard Error & 0,0303 \\
Observations & $\mathbf{1 1}$ \\
\hline
\end{tabular}

\begin{tabular}{|c|c|c|c|c|c|}
\hline & $d f$ & SS & $M S$ & $F$ & Significance $F$ \\
\hline Regression & 3 & 0,1903 & 0,0634 & 69,2015 & $5 \quad 1,44061 \mathrm{E}-05$ \\
\hline Residual & 7 & 0,0064 & 0,0009 & & \\
\hline Total & 10 & 0,1967 & & & \\
\hline
\end{tabular}

\begin{tabular}{|c|c|c|c|c|c|c|c|c|}
\hline & Coefficients & rd Error & $t$ Stat & P-value & Lower 95\% & Upper 95\% & Lower $95,0 \%$ & Upper $95,0 \%$ \\
\hline Intercept & 2,0661 & 0,4132 & 4,9997 & 0,0016 & 1,0889 & 3,0433 & 1,0889 & 3,0433 \\
\hline 1 st Pillar & 0,5977 & 0,0798 & 7,4904 & 0,0001 & 0,4090 & 0,7864 & 0,4090 & 0,7864 \\
\hline 3 rd Pillar & 0,2217 & 0,0565 & 3,9272 & 0,0057 & 0,0882 & 0,3552 & 0,0882 & 0,3552 \\
\hline 11 th Pillar & $-0,2611$ & 0,1622 & $-1,6103$ & 0,1514 & $-0,6446$ & 0,1223 & $-0,6446$ & 0,1223 \\
\hline
\end{tabular}




\section{The International Journal}

ENTREPRENEURSHIP AND SUSTAINABILITY ISSUES

ISSN 2345-0282 (online) http://jssidoi.org/jesi/

2018 Volume 5 Number 3 (March)

http://doi.org/10.9770/jesi.2018.5.3(13)

$$
\operatorname{GCI}(\mathrm{SR})=2.0661+0.5977 * \mathrm{P} 1+0.2217 * \mathrm{P} 3
$$

In the end of study we formulate the final regression model by using the key determinants (pillar P1: Institutions, pillar P3: Macroeconomic environment and pillar P11: Business sophistication). Our model explains $96.74 \%$ of variability, which means that the determination factor $\left(R^{2}\right)$ is 0.9674 . Significance $F$ value is $1,44^{-5}$ and it means that model has predictive capability. As the regression analysis indicates the statistically significance relation was confirmed among pillar P1: Institutions, pillar P3: Macroeconomic environment and the value of GCI(SR). The statistically significant relationship was not confirmed for the other pillar. As the variables presents, increasing the value of the pillar $P 1$ by one unit will cause an increase in the overall index value by 0.5977 points and increasing the value of the pillar $P 3$ by one unit will cause an increase of GCI value by 0.2217 points. On the basis of these results we can state that our created model confirmed a statistically significant relation between pillar P1, P3 and total GCI value.

\section{Conclusions and recommendations}

In terms of strategic development, all countries in the world as well as European countries would like to be competitive and able to secure sustainable economic growth in a long-term context. Creating a generally accepted and comprehensive model measuring the international competitiveness with the ability of sustainable growth is not a simple task. In the last few decades, many organizations dealing with this area have been created, but the diversity of results led to a lot of professional and research discussions about which methodological approach is more appropriate, objective, complex and more fulfils the condition of multi-criteriality.

This paper was focused on the objectivity and differences evaluation of the resulting GCI and WCI composite indexes within the EU(24) countries during the years 2006 - 2016 through an in-depth analysis of the approaches and calculation methodologies for both world rankings. The GCI and WCI indexes are considered the world's most respected, so it is difficult to clearly determine which of these rankings is the right one and can more objectively measure the countries' competitiveness. Both institutions and indexes compiled by them have advantages as well as disadvantages. The longer history of WEF compared to IMD is reflected in richer experiences and stable long-lasting partnerships. This creates the appropriate preconditions for undertaking a wider global study. The final score of GCI indicator is distorted by using especially the "soft data" that are less comparable because of subjective assessment of respondents. However, the WEF monitors many more countries and respondents in the survey than IMD which results in reducing the possibility of data distortion. The "soft data" also have another advantage - they can express difficult-to-quantifiable elements of competitiveness and their obtaining is not affected by time delay. The total number of criteria observed in the calculation of the WCI indicator considerably exceeds the number of individual indicators forming the complex structure of the GCI indicator. This combination with the prevalence of statistical data from different sources contributes to increasing the objectivity of the WCI indicator score. Complete Global Competitiveness Reports are publicly available on the WEF's websites without any charges. They provide certain overview to all interested subjects and lead them to discuss about issues of international competitiveness. On the other hand, the IMD's World Competitiveness Yearbooks are available in full version only for a fee, which is not negligible.

By analyzing the GCI and WCI scores achieved within the EU(24) countries over the analysed years 2006 - 2016, we found out that the average value of the GCI score for selected EU(24) countries was at the level of 4.79; for the WCI score it was slightly lower (4.72). The development of the average GCI score had a relatively stable trend, while in the case of the WCI index countries reached unstable scores. The average GCI score of the EU(24) countries has decreased by $1.62 \%$, vice versa, the positive increase of $18.52 \%$ was noticed in the case of the average WCI score. This fact undoubtedly raises many questions about the real development of EU(24) countries' competitiveness. In order to reveal the most significant positions' deviation in these two world competitiveness 
rankings we focused on summarizing the resulting average rankings of each country over the analzed years and found out the following results:

- the same average position in the WEFs' and IMDs' rankings was revealed in the case of 6 countries,

- the worse average rank in the WEFs' rankings as IMDs' was recorded in the case of 7 countries,

- the worse average position in the IMDs' rankings than the WEFs' was revealed in the case of 11 countries.

Based on the results of the GCI(SR) regression analysis, we point out that the following economic and statistical developments were confirmed:

- within the first subindex "Basic requirements" are the key determinants of the Slovakia's global competitiveness pillars P1: Institutions (especially factor Public trust in politicians), and P3: Macroeconomic environment, expecially factor Government debt;

- the third key determinant of the Slovakia's global competitiveness within the third subindex "Innovation and sophistication factors" is pillar P11: Business sophistication, especially factor Nature of competitive advantage;

- all pillars of the GCI(SR), except of the pillar P3: Macroeconomic environment, which were statistically and economically identified as key, were rated as one of the weakest and in the future it is necessary to identify the causes that prevent their progressive growth;

- a statistically significant relation among pillars P1, P3 and total GCI value on the basis of our created model.

Despite these reservations on approaches and methodology of measuring countries' competitiveness through these indices, we can state that the position of countries in world rankings and the achievements of both composite indexes (especially results in critical areas that pose a particular threat to sustainable growth of Slovakia, in particular, factors within the pillars P1, P11 and P12 (see Table 4) with the lowest average pillar values of the $\mathrm{GCI}(\mathrm{SR})$ ) should be taken into account in the development of the national economic policy, but with a certain reserve. Country results are often distorted by adjusting the number of countries evaluated, so it is important to look at partial relative indicators as well as the development of the business environment in other competitive economies. Based on the results published by global organizations concerned with the national competitiveness we can state that countries that have placed in leading positions put the greatest emphasis on these factors - the knowledge economy, research, innovation, technology and IT sector. So all these factors we consider as key factors for global competitiveness and sustainable growth.

\section{Acknowledgements}

This work was supported by the Slovak Research and Development Agency under the contract No. APVV-150322.

\section{References}

Abrhám, J.; Herget, J. 2013. Approaches to the Assessment of the Factors of Competitiveness and Long Term Growth, Political Sciences 16(2): 98-109. Retrieved from http://www.politickevedy.fpvmv.umb.sk/archiv-vydani/2013/2-2013/

Balcarová, P. 2015. Competitiveness of the European Union: Converging or Diverging Tendency? The 18 $8^{\text {th }}$ International Conference "Enterprise and the Competitive Environment", Ed. by Kapounek, S. March 05-06, Brno, Czech Republic. Brno: Univ. Mendel, 36-45.

Bris, A. 2016. IMD World Competitiveness Yearbook 2016. Lausanne, Switzerland: Published by IMD: Institute for Management Development.

Despotović, D.; Cvetanović, S.; Nedić, V.; Despotović, M. 2016. Economic, Social and Environmental Dimension of Sustainable Competitiveness of European Countries, Journal of Environmental Planning and Management 59(9): 1656-1678. https://doi.org/10.1080/09640568.2015.1085370

Dobrovič, J.; Korauš, A.; Dančišinová, L. 2016. Sustainable Economic Development of Slovakia: Factors Determining Optimal Tax Collection, Journal of Security and Sustainability Issues 5(4): 533-544. Retrieved from http://jssidoi.org/jssi/uploads/papers/20/Dobrovic_Sustainable_economic_development_of_Slovakia_factors_determining_optimal_tax_col lection.pdf 


\section{The International Journal}

ENTREPRENEURSHIP AND SUSTAINABILITY ISSUES

ISSN 2345-0282 (online) http://jssidoi.org/jesi/

2018 Volume 5 Number 3 (March)

http://doi.org/10.9770/jesi.2018.5.3(13)

Dudáš, T. 2012. Competitiveness Development of the Visegrad Group in the Light of the International Competitiveness Indices During the Years 2001 - 2011, Journal of International Relations 10(2): 58-71. Retrieved from http://fmv.euba.sk/RePEc/brv/journl/MV2012-2.pdf

Dudáš, T. 2013. Methodical Background of Global Indices of National Competitiveness. The 14 ${ }^{\text {th }}$ International Relations 2013 "Contemporary Issues of World Economics and Politics” Ed. by Lipková, L'; Kucharčík, R. December 05-06, Smolenice, Slovak Republic, 192-201.

Fabuš, M. 2015. Current Development of Business Environment in Slovakia and Czech Republic, Entrepreneurship and Sustainability Issues 5(1): 127-137. http://jssidoi.org/jesi/article/138

Gavurova, B.; Virglerova, Z.; Janke, F. 2017. Trust and a Sustainability of the Macroeconomic Growth Insights from Dynamic Perspective, Journal of Security and Sustainability Issues 6(4): 637-648. Retrieved from http://jssidoi.org/jssi/uploads/papers/24/Gavurova_Trust_and_a_sustainability_of_the_macroeconomic_growth_insights_from_dynamic_p erspective.pdf

Gordiaková, Z. 2011. Evaluation of the countries' competitiveness, The International Scientific Conference "YOUNG SCIENTISTS 2011", Košice, Slovak Republic. Košice: Technical University of Košice, 121-133.

Chudárková, S. 2012. Competitiveness of the Visegrad Group Countries. The 10 ${ }^{\text {th }}$ International Scientific Conference "Economic Policy in the European Union Member Countries" Ed. by Tvrdon, M.; Majerova, I. September 19-21, Vendryne, Czech Republic, 94-104.

Illmeyer, M; Grosch, D.; Kittler, M.; Priess, P. 2017. The Impact of Financial Management on Innovation, Entrepreneurship and Sustainability Issues 5(1): 58-71. http://jssidoi.org/jesi/article/133

IMD, 2014. IMD World Competitiveness Yearbook 2014. Lausanne, Switzerland: Published by IMD: Institute for Management Development.

IMD, 2016. IMD World Competitiveness Yearbook 2016. Lausanne, Switzerland: Published by IMD: Institute for Management Development.

Ivanová, E.; Kordoš, M. 2015. Competitiveness versus Economic Performance of V4 States, Social and Economic Revue 13(1): 15-24. Retrieved from http://fsev.tnuni.sk/fileadmin/veda_a_vyskum/SER/2015/Socialno_ekonomicka_revue_volume_1_2015.pdf

Ivanová, E.; Kordoš, M.; Habánik, J. 2015. The Competitiveness of V4 Countries in the European Union, Actual Problems in Economics, 5(167): 39-49.

Jurigová, Z.; Tučková, Z.; Solenes, O. 2017. The Impact of Chosen Economic Indicators on Tourism Sustainability: Case Study of the Czech Republic and Norway, Journal of Security and Sustainability Issues, 7(1): 113-121. Retrieved from http://jssidoi.org/jssi/uploads/papers/25/Jurigova_The_impact_of_chosen_economic_indicators_on_tourism_sustainability_case_study_of_ the_Czech_Republic_and_Norway.pdf

Kisel'áková, D.; Šofranková, B.; Čabinová, V. 2016. Analytical View on the Competitiveness Development in the Slovak Republic and in the EU, Acta Aerarii Publici 2(13): 55-68.

Loo, M., K. 2012. Competitiveness: Top Five Nations Last Decade And Next Decade, International Journal of Business and Management Studies 1(3): 391-412. Retrieved from http://www.openaccesslibrary.org/images/ULV227_Mark_Loo.pdf

Loo, M., K. 2015. The Global Competitiveness of BRIC Nations: Performance, Issues and Implications for Policy, Review of Integrative Business and Economics Research 4(4): 22-62. Retrieved from http://sibresearch.org/uploads/2/7/9/9/2799227/riber_s15-031_22-62.pdf

Majerová, I.; Horúcková, M. 2014. Competitiveness of Selected European Countries and its Measurement through the GCI, The 24t ${ }^{h}$ International Business-Information-Management-Association Conference "Crafting Global Competitive Economies: 2020 Vision Strategic Planning \& Smart Impementation” Ed. by Soliman, KS. November 06-07, Milan, Italy, 1446-1457.

Mikušová Meričková, B.; Nemec, J.; Murray Svidroňová, M.; Pischko, V. 2017. Analysis of the Relationship between the Size and Structure of Public Expenditure and Socio-Economic Development, Journal of Economics 64(4): 320-333.

Nečadová, M. 2015. Concepts of Firm and National Competitiveness and Changes in Competitiveness of Visegrad Group Countries, The $9^{\text {th }}$ International "Days of Statistics and Economics" Ed. by Loster, T.; Pavelka, T. September 10-12, Prague, Czech Republic, $1169-1179$. Ochotnický, P.; Lajzová, B.; Kiseláková, D. 2011. Price Competitiveness and Taxation of Energy Inputs, Journal of Economics 59(8): 786-801.

Paraušić, V. et al. 2014. Correlation Between the State of Cluster Development and National Competitiveness in the Global Competitiveness Report of the World Economic Forum 2012-2013, Economic Research 27(1): 662-672. https://doi.org/10.1080/1331677X.2014.974917

Popescu, G. H.; Sima, V.; Nica, E.; Gheorghe, I. G. 2017. Measuring Sustainable Competitiveness in Contemporary Economies - Insights from European Economy, Sustainability 9(7): 1-26. https://doi.org/10.3390/su9071230

Porter, M. E. 1994. Selected Competitive Strategy: Methods for Sector and Competitor Analysis. Praque: Victoria Publishing.

Ružeková, V.; Kašt'áková, E.; Žatko, E. 2016. Comparison of the V4 Economies According to International Competitiveness Indices and the Basic Pillars of the Knowledge Economy. The $3^{\text {rd }}$ International Conference "European Integration 2016" Ed. by Kovarova, E.; Melecky, L.; Stanickova, M. May 19-20, Ostrava, Czech Republic, 838-848.

Sala - I - Martín, X. et al. 2014. The Global Competitiveness Report 2014-2015. Retrieved from http://www3.weforum.org/docs/WEF_GlobalCompetitivenessReport_2014-15.pdf

Sala - I - Martín, X. et al. 2015. The Global Competitiveness Report 2015-2016. Retrieved from http://www3.weforum.org/docs/gcr/20152016/Global_Competitiveness_Report_2015-2016.pdf 


\section{The International Journal}

ENTREPRENEURSHIP AND SUSTAINABILITY ISSUES

ISSN 2345-0282 (online) http://jssidoi.org/jesi/

2018 Volume 5 Number 3 (March)

http://doi.org/10.9770/jesi.2018.5.3(13)

Sala - I - Martín, X. et al. 2016. The Global Competitiveness Report 2016-2017. Retrieved from http://www3.weforum.org/docs/GCR2016-2017/05FullReport/TheGlobalCompetitivenessReport2016-2017_FINAL.pdf

Schneider, S.; Spieth, P. 2013. Business Model Innovation: Towards an Integrated Future Research Agenda, International Journal of Innovation Management, 17(1), 1-34. Retrieved from http://www.worldscientific.com/doi/pdf/10.1142/S136391961340001X

Staníčková, M.; Melecký, L. 2011. Competitiveness Evaluation of Visegrad Four Countries by CCR Input Oriented Model of Data Envelopment Analysis, Scientific Papers of the University of Pardubice - Series D 16(22): 176-188. Retrieved from http://www.upce.cz/fes/veda-vyzkum/fakultni-casopisy/scipap/archiv/e-verze-sborniku/2011/sbornik-4-2011.pdf

Tokárová, M. 2015. Selected Problems of Competitiveness Measuring in Conditions of Globalization, The 15 $5^{\text {th }}$ International Scientific Conference "Globalization and its Socio-Economic Consequences" Ed. by Kliestik, T. October 07-08, Rajecke Teplice, Slovak Republic, 800-809.

Tomčík, R.; Bondareva, I. 2015. Comparison of Economic Development of the Slovak Republic and the Czech Republic Based on Global Competitiveness Index, Scientific Papers of the University of Pardubice 22(33): 6-16. Retrieved from http://www.upce.cz/fes/vedavyzkum/fakultni-casopisy/scipap/archiv/e-verze-sborniku/2015/scipap-33-2015.pdf

Dana Kisel'áková is the Associate Professor of Management with focus on Financial Management and Head of Department of Finance at Faculty of Management, University of Presov in Presov, Slovak Republic. At the same time she is the co-guarantor of PhD study at Faculty of Management. She is currently the principal investigator of scientific projects VEGA number 1/0791/16 and APVV-15-0322 with cooperation of University of Economics in Bratislava. She has published more than 150 publications, including scientific monographs, textbooks, and scientific studies in scientific journals, some of in international database Web of Science and Scopus. As a co-author she has published three scientific studies in the scientific journal - Journal of Economics, indexed in Web of Science, Current Contents. Research interests are: financial management of enterprises and investment, enterprise performance management, risk controlling, competitiveness of economies and regional development, and banking.

Beáta ŠOFRANKOVÁ works as a senior lecturer and secretary of the Department of Finance at the Faculty of Management University of Presov in Presov. She has published more than 100 publications, including scientific monographs, textbooks, and scientific studies in scientific journals and outputs from domestic and international conferences, some of them are published in international database Web of Science and Scopus. Her research work is focused on financial and risk management, methods for assessing the performance of business entities and financial - economic analysis.

Veronika ČABINOVÁ is a PhD. student at the Department of Finance, Faculty of Management, University of Prešov in Prešov. Her dissertation thesis is focused on modern approaches of improving enterprise performance to streamline management decision - making processes. She is currently the member of scientific projects VEGA number 1/0791/16 and APVV-15-0322 with cooperation of University of Economics in Bratislava.

Erika ONUFEROVÁ is a PhD. student at the Department of Finance, Faculty of Management, University of Prešov in Prešov. Her dissertation thesis is focused on managerial approaches to improving enterprise performance and competitiveness using to streamline strategic management decision-making processes. She is currently the member of scientific projects VEGA number 1/0791/16 and APVV15-0322 with cooperation of University of Economics in Bratislava.

ORCID ID: orcid.org/0000-0002-9667-3730

Register for an ORCID ID:

https://orcid.org/register

Copyright (C) 2018 by author(s) and VsI Entrepreneurship and Sustainability Center

This work is licensed under the Creative Commons Attribution International License (CC BY).

http://creativecommons.org/licenses/by/4.0/

(c) (i) Open Access 